\title{
COXEN Score 19
}

National Cancer Institute

\section{Source}

National Cancer Institute. COXEN Score 19. NCI Thesaurus. Code C128216.

A score of 19 on the COXEN Sensitivity Scale. 